\title{
Knowledge and Opinion toward Sex Education among Selected Secondary School in Ejigbo Local Government Area, Osun State, Nigeria.
}

\author{
B.L. Ajibade ${ }^{1}$, Olagunju,R.O. ${ }^{2}$, Oyediran, $\mathrm{G}^{3}$. \\ Department of Nursing Science, College of Health Sciences, Osogbo. LAUTECH, OGBOMOSO.
}

\begin{abstract}
Introduction /Background: This study was designed to find out the altitude of selected adolescents towards sex education in Osun State, Nigeria. It was designed to enlighten the adolescent on the problems associated with lack of sex education.
\end{abstract}

METHODOLOGY

This is a descriptive study using multistage sampling technique to select the 3 secondary schools in Ejigbo local government area. The respondents were selected using simple random technique through the register of the school. The instrument used was a self-designed questionnaire with reliability of 0.71 using spearman brown coefficient analysis. Three hundred (300) respondents were used for the study.

RESULTS.

Findings showed that, adolescents level of knowledge on sex matter was poor with a greater percentage (53\%) affirming this. On the meaning of sex majority of respondent (60\%) said it has to do with touching of body parts.

CONCLUSION

It was concluded that sex education should be adopted to avoid consequent of lack of sex education.

Keywords: Knowledge, attitude, Adolescents, sex education.

\section{Introduction}

Sex is a word that so many youths in our society are not comfortable to discuss it. Early sex training among the youths is very vital because young people have the right to be exposed gradually to proper and responsible education on fertility awareness and ideas about sex education.

Sex is seen as physical activity between two people in which they touch each other's sexual organs which may involve sexual intercourse (Achilia, 2002). George (1999) in encyclopedia of education defines sex education as "the teaching of human sexuality and the state and function of being a sexual person and a way to helping children grow into adulthood without getting into sex related troubled". The biological, physiological and physical changes in adolescents make them to ask many questions regarding sex and sexuality and many times, there would be no enlightened person to give an appropriate, answer. In some societies, discussing such matters is a taboo and in some cases, those who attempted answering, do it ha p-hazardly(Agujiobi,2003) Nwabuichic (2001) looks at sex education as an education which deals with instruction to develop understanding of physical, emotional are psychological phase of human relation as they are affected by male and female.

Gold man (1999) stated that, "as long as a girl is kept in absolute ignorance of the meaning and importance of sex, she will not be able to take care of herself" so one need not be surprised if she becomes an easy prey to prostitution ." more (2000) asked,"why do we put more effort into teaching of history or religion and totally neglecting the historical evolution of human sex".

He went further to argue that just as we discuss how to cook, farm, read and write to our children, we should also endeavour to teach our children the revolution of sex. We should there for teach our children how we came into the world and the consequences surrounding it.

Akindele (2002) criticized the theory of keeping children in an "artificial ignorance" in sex matters. She stated that, "The fact that a mystery is made about sex, there is naturally an increasing curiosity of the discourse on the subject". Therefore, the best way to prevent the young people from being occupied in mind with sex is to tell them as much as they can understand it. She also asserted that parents should gradually and progressively scare their sexual experience and enlightment with their children, since the primary goal of sex education is to provide the individual knowledge and concept that will enable him to make informed and responsible decision about sexual behaviour at all stages of life.

Agujiobi (2003) asserted that many youths today experience embarrassment after having been left in darkness from childhood and happens to stumble into the fact of life. Some girls attain the age of puberty 
without undergoing any form of sex education. Such girls experience shock at the first appearance of menstrual flow.

Most of our young adolescent girls do not have adequate sex education. Their age grades can deceive them to have sexual affairs with them and in the process they can become pregnant and in abid to get out of it, they will implicate the issue by visiting quacks and sometimes death results in the process.

Statistics and surveys revealed that sexual attitudes and practices have changed towards greater permissiveness with a resultant increase in premarital intercourse, illegitimate births, illegal abortions and sexually transmitted infections. Avoid sex education will give the child a natural and mature attitude towards sexually and provide a firm ground for the child's marriage and family life. Sex education is therefore, recommended to create awareness to the children on the consequences of their secret affairs with their opposite sexes and the resultant effects on the association (Adeyemo, 2007).

Pearsons (2000) in his opinion asserted that the qualifying measure for a teacher to handle sex education include - knowledge of biology as well as current research and easy disposition towards sexually. To him, knowledge alone is not enough rather, people who are at easy with their own sexually, should be asked to deal with it in the classroom for they are likely to be successful. Hiller (1999) in his own opinion suggested that sex education should be taught in biology, health education or literature class. He also posited that greater sex education should be given in the homes by emotionally well adjusted teachers and religious leaders, because he believed that effective teaching of sex education needs honesty, accuracy and dialogue.

\section{Methodology}

\section{Study Design}

The design adopted for this study was a descriptive survey. This design was adopted as no part of the variables was manipulated but they were describe as they occurred in the research.

\section{Study Setting}

The research study was carried out at the Ejigbo local government area. Ejigbo local government was one of the oldest local government in Osun State, South West of Nigeria. It has eleven (11) wards. It has boundaries with Surulere local government (Oyo State). It has twenty five (25) senior secondary school (both private and public).

Sample Size And Sampling Technique: The sample size was 300. The sampling Technique adopted was Multistage Sampling. The secondary schools in the local government were first clustered and three (3) schools were randomly selected from the sampling frame.

The schools selected were stratified into sets (i.e. SSS I - 3). The Registers of the selected set was recalled and simple random technique was used to selected the final respondents for the study.

Inclusion Criteria:-

- The student must be between ages 11-19 years old

- Ability to read and write in English Language.

Instrument for Data Collection:- The instrument used for the study was self designed questionnaire. The instrument was subjected to face validity and coefficient alpha 0.74 using Craibach alpha.

Data Analysis Method:- Data collected were analyzed using descriptive analysis in form of fasles, frequencies and percentage.

\section{Results}

The findings of this study revealed that the adolescent had inadequate knowledge about sex education as majority of the respondents (53\%) do not really understand the meaning of sex education, they reasoned that it is a means of corrupting the youths, and $27 \%$ indicating it as a process of teaching young people bad things. Only $20 \%$ believes that it is the information and teaching about sex matters an individual involves himself I harvest (Table I).

On the attitude of adolescents towards sex education, majority of them (60\%) agree that they have boy or girl friends while $40 \%$ were on the contrary, in relation to the kind of sexual activities they engaged in, a greater percentage $(60 \%)$ said they engage in touching their body parts, $27 \%$ engage themselves in kissing while $13 \%$ asserted they engage in sexual intercourse (Table 2).

The study also revealed that, majority of the respondents $(50 \%)$ said they are aware that it on lend to contracting HIV/AIDs, $17 \%$ said it can lead to malaria, $13 \%$ said gonorrhea can be gotten from the opposite sex due to lack of sex education while $10 \%$ asserted that syphilis and typhoid fever can be gotten respectively through sexual intercourse, and on the other hand, majority of the respondents (67\%) were not aware that lack of sex education can lead to any other problem while $33 \%$ asserted that it can lead to any other problems. 
Forty percent agreed that it can lead to unwanted pregnancy, some (27\%) said criminal abortion and $20 \%$ said conflict in the home while $13 \%$ said it can lead to child abandon cement (Table 4).

Table 5 shows that, a greater percentage $(67 \%)$ of the respondents asserted that, sex education can inform people of changes that occur in the body while $33 \%$ were on the contrary. The table also shows the changes that occur in the body in which $40 \%$ asserted that it is menstrual cycle $33 \%$ enlargement of the breast and $80 \%$ said, it is widening of the hip. It also reveal the majority of the respondents $(60 \%)$ are not aware that sex education can prevent unwanted pregnancy while $40 \%$ said it can prevent it.

Table1: Respondents knowledge Sex education.

\begin{tabular}{|l|l|c|c|}
\hline \multicolumn{1}{|c|}{ Variable } & \multicolumn{1}{|c|}{ Options } & Frequency & Percentage \\
\hline $\begin{array}{l}\text { What do you understand } \\
\text { by sex education }\end{array}$ & $\begin{array}{l}\text { a) Sex education is the process of teaching } \\
\text { young people bad thing } \\
\text { b) Sex education is the information and } \\
\text { teaching of sex matters involved in life. } \\
\text { c) Sex education is a means of corrupting the } \\
\text { youths. }\end{array}$ & 80 & 27 \\
\hline Total & & 60 & 160 \\
5
\end{tabular}

Table2: Respondents on attitude towards Sex education

\begin{tabular}{|c|c|c|c|}
\hline Variable & Options & Frequency & Percentage (\%) \\
\hline $\begin{array}{l}\text { Do adolescent have boy or girl } \\
\text { friends.? } \\
\text { What kind of sexual relationship do } \\
\text { adolescent engaged in? }\end{array}$ & $\begin{array}{l}\text { Yes } \\
\text { No } \\
\text { a) Kissing } \\
\text { b) Touching } \\
\text { c) Sexual Intercourse }\end{array}$ & $\begin{array}{c}180 \\
120 \\
80 \\
180 \\
40\end{array}$ & $\begin{array}{l}60 \\
40 \\
27 \\
60 \\
13\end{array}$ \\
\hline Total & & 300 & 100 \\
\hline
\end{tabular}

Table 3: Responses on the wind of diseases resulting from lack of sex Education.

\begin{tabular}{|c|c|c|c|}
\hline Variable & Options & Frequency & Percentage \\
\hline $\begin{array}{l}\text { Mention any } 3 \text { diseases } \\
\text { that can be gotten through } \\
\text { sexual intercourse }\end{array}$ & $\begin{array}{l}\text { a) Gonorrhea } \\
\text { b) Malaria } \\
\text { c) Syphills } \\
\text { d) Typhoid } \\
\text { e) HIV/AIDS }\end{array}$ & $\begin{array}{c}40 \\
50 \\
30 \\
30 \\
150 \\
\end{array}$ & $\begin{array}{l}13 \\
17 \\
10 \\
10 \\
50\end{array}$ \\
\hline Total & & 300 & 100 \\
\hline
\end{tabular}

Table 4: Responses on other problems resulting from lack of education.

\begin{tabular}{|l|l|l|l|}
\hline \multicolumn{1}{|c|}{ Variable } & \multicolumn{1}{|c|}{ Options } & \multicolumn{1}{c|}{ Frequency } & \multicolumn{1}{c|}{ Percentage\% } \\
\hline Can lack of sex education & Yes & 100 & 33 \\
lead to any problem? & No & 200 & 67 \\
If yes what problem. & & 60 & 20 \\
& a) Conflict in the home. & 40 & 13 \\
& b) Child abandonment & 120 & 40 \\
& c) Unwanted Pregnancy & 80 & 27 \\
\hline & d) Criminal abortion & $\mathbf{3 0 0}$ & $\mathbf{1 0 0}$ \\
\hline
\end{tabular}

Table 5: Responses on the importance of sex education.

\begin{tabular}{|c|c|c|c|}
\hline Variable & Options & Frequency & $\begin{array}{c}\text { Percentag } \\
\text { e } \%\end{array}$ \\
\hline $\begin{array}{l}\text { Can sex education inform people of changes that } \\
\text { occur in the body? } \\
\text { If yes what changes. }\end{array}$ & $\begin{array}{l}\text { Yes } \\
\text { No } \\
\text { a) Menstrual cycle } \\
\text { b)Enlargement of the } \\
\quad \text { breast. } \\
\text { c) Widening of the hip } \\
\text { d) Others specified } \\
\text { Yes } \\
\text { No }\end{array}$ & $\begin{array}{c}120 \\
100 \\
80 \\
0 \\
60 \\
240\end{array}$ & $\begin{array}{c}40 \\
\\
27 \\
33 \\
0 \\
\text { s20 } \\
80\end{array}$ \\
\hline
\end{tabular}

\section{Discussion}

It was discovered from the findings that majority of the respondents do not really understand the meaning of sex education as they asserted that it is a means of corrupting the youths due to inadequate 
knowledge. This supports the work of Akindele (2003) who criticized the theory of helping children in an artificial ignorance.

This finding also revealed a variation on the attitude of adolescents towards sex education which agrees with Achilla, (2002). On issues and problems relating to family life and sex education for boys and girls, which showed that sexual attitude and practice have changed towards greater permissiveness with resultant increase in premarital intercourse illegitimate births and sexually transmitted infections. The study also revealed that majority of respondents engagement in sexual activity is due to naturally, increasing curiosity of the young on the subject which tends to agree with the work of moore (2000) who said we should endeavour to teach our children the revolution of sex, how we came into the world and the consequences of engaging in illiat sexually activity.

Among other findings, it was realized that majority of the adolescents were not adequately informed about the changes. In their body due to lack of sex education. Also majority of them did not now that sex education can prevent unwanted pregnancy this was attributed to the fact that their parents did not furnish them with adequate knowledge about procreation. This corroborales the work of Agujiobi (2003) that the adolescent girls do not have adequate knowledge of the process of procreation due to inadequate information about sex education and because of this, their males can in-pregnant them without precaution.

\section{Conclusion and recommendations}

The study concluded that most of the adolescents in our secondary schools in Udenu local government.

Area of Enugu state do not have adequate knowledge about sex education as discussion on matters related to human sexually have always been done with some reservation this heaving. Our youths in ignorance and dangers of irresponsive sexual behaviour as portrayed in their attitude. In view of those factors, the following are recommended.

a). Parents should give their children enough information about sex education as soon as the child is due for it.

b). Sex education should be included in the curriculum of studies at the college level.

c). Efforts should be made by the government to improve the knowledge of adolescent by establishing standard schools and adequate teachers with requisite knowledge about sex education especially those with a good background of biology and who can handle their sexually adequately.

d). The health workers, non-government agencies and religious leaders should also Organize programmes on sex education from time to time.

\section{References.}

[1]. Achilla, M. (2002). Issues and Problems in Introducing Family Life education for boys and girls of secondary schools. Journal of Family welfare 38 (I): $56-67$

[2]. Adeyemo, M.O. (2007) Dissemination of family Life education to adolescents by their parents suburden Ibadan, Nigeria. 22-49.

[3]. Agujiobi, B. (2003): Need for sex Education in Our Schools Adewumi Printing Press, Ibadan, Nigeria. 22-49.

[4]. Akindele, J. (2002): Human Sexual Responses, Gribina Publishing Company, Lagos, Nigeria pp 37-62.

[5]. George, D.P (1999):Enciclopedia of Education, Spain Editorial Sufeliz Limited 8:192.

[6]. Goldman, M(1999): Sex Education for youths and parents Magill Publishing Co. Mumbai pp 19-50.

[7]. Hiller, L.(2000): Sexually and Diversity in Rural youth. American Garland publishing inc. U.S.A, 83-98

[8]. Moore, s.(2000): Sexuality in adolescents Routledge publishers, U.S.A, 105-161.

[9]. Nwabuichie, J.(2001) Sex and Moral Behaviour Cimong the youth, Delta publication Limited Nigeria,55-7.

[10]. Pearsons. k (2000): Adolescent value system preferred Resolution Strategies and conflict with parents Australian Journal of psychology 5(2):63-70. 